\title{
The Role of Governance in Attracting Foreign Direct Investment in Arab Countries
}

\author{
Dr. Al Siddig Talha Mohed Rahma \\ Associate Economic Professor, Imam Mohammed Ibn Saud Islamic University (KSA), National Ribat University (Sudan)
}

\begin{abstract}
The growing interest in governance in many developed and developing economies in recent years, especially in the wake of the economic collapses and financial crises witnessed by a number of East Asian countries, Latin America and Russia in the nineties of the twentieth century; and also witnessed the US economy from the repercussions of those financial and accounting collapses of a number of American International Companies during 2002. The Arab countries followed suit in their attempts to implement the standards of governance. The concept of governance, its roots, its objectives and the reasons for its need.
\end{abstract}

Keywords: government, foreign, investment .Arab ,countries

\section{Definition of Governance}

The definitions of the term "governance" have varied in many ways, with a variety of people interested in the term and their political, cultural, economic and social affiliations, so that each definition reflects the viewpoint adopted by the author of this definition.

IFC defines governance as "the system through which companies are managed and controlled"

As defined by the Organization for Economic Co-operation and Development (OECD) as "a set of relationships among the directors of the company, the board of directors, shareholders and other shareholders".

There are those who define it as: "the total" rules of the game "used to manage the company from the inside, and for the board of directors to oversee them to protect the interests and financial rights of the shareholders." In other words, governance means the system, As well as the long-term strengthening of the institution and the identification of responsibility and responsibility.

\subsection{Roots of Corporate Governance}

The economic literature on corporate governance suggests that economists Berle and Means were among the first to address the separation of ownership from management in 1932, where corporate governance mechanisms were considered to bridge the gap that could occur between managers and owners of the company due to negative practices that could harm the company and industry as a whole. In 1937, Ronald Coase published his first article on how to reconcile the owners and managers of the company. In 1979, Jensen and Meckling addressed the "agency problem" as referring to the inevitability of a conflict in the company when there is a separation between Property and management. In this context, they stressed the possibility of solving the problem of the Agency through the good application of the mechanisms of governance of evil

The importance of the concept of corporate governance has increased, with a number of international institutions addressing this concept with analysis and study. These institutions are headed by the International Monetary Fund and the World Bank, the International Center for Private Enterprise and the Organization for Economic Co-operation and Development (OECD), Which aims at assisting both Member States and non-members of the Organization to develop legal and institutional frameworks for the application of corporate governance in both public and private companies, both written and non-subscribed to the capital markets, through the introduction of a number of guidelines to strengthen corporate governance, Money and stability of the economy as a whole. The 1999 Five Principles of the OECD address corporate governance applications for the preservation of shareholders' rights, the fair treatment of shareholders, the role of stakeholders, disclosure and transparency, and the assertion of the responsibility of the Board. In 2004, the Organization for Economic Cooperation and Development A new list of corporate governance standards, adding an indicator of securing the foundations for an effective corporate governance framework. Recently, the importance of corporate governance has increased significantly to achieve both the economic and legal development and social welfare of economies and societies.

"Corporate Governance" has become an important part of the economics literature following the bankruptcy of some major international companies such as Enron and WorldCom, and other international companies are facing major financial difficulties such as Swissair and France Telecom, according to a report issued in 2000 by a Swiss bank especially addressing corporate governance and corporate social responsibility.

\subsection{Corporate Governance Objectives}

Governance rules and regulations seek to achieve a set of objectives, the most important of which can be summarized as follows:

- Taking into account the interests and rights of shareholders and protecting them.

- Protecting the rights of policyholders and documents related to the effectiveness of companies.

- Protecting the rights and interests of employees in companies of all categories.

- Achieve transparency in all businesses.

\section{Volume 6 Issue 12, December 2017}

\section{www.ijsr.net}




\section{International Journal of Science and Research (IJSR) \\ ISSN (Online): 2319-7064}

Index Copernicus Value (2016): 79.57 | Impact Factor (2015): 6.391

- Achieve justice for all stakeholders and clients.

- Secure the right of accountability before the owners of rights to manage companies.

- Limit the exploitation of power in the public interest.

- Developing savings and encouraging their flow, which will lead to the development of productive investments in order to maximize profits and away from monopolies.

- Compliance with the provisions of the laws and legislation in force.

- Ensuring performance audit for all corporate activities including financial performance through external review committees and independent of executive management.

- Accounting of executive management in front of shareholders.

\subsection{Reasons for the need for corporate governance in developing countries:}

Governance in many developed and emerging countries has emerged over the past few decades, especially in the wake of economic collapses and financial crises in East Asia, Latin America and Russia in the 1990s, as well as the recent financial and financial collapses in the US economy. In 2002. The importance of governance has increased as a result of the tendency of many countries of the world to shift to capitalist economic systems, which rely heavily on private companies to achieve high and sustained rates of economic growth. The expansion of these projects has led to the separation of ownership from management, and these projects have begun to seek lower-cost sources of finance from banking sources, addressing the financial markets. This was supported by the liberalization of financial markets, the unprecedented trans-border transfer of capital, the expansion of corporate size and the separation of ownership from management into weak supervisory mechanisms for managers' actions, and many companies in financial crises. Most notably South-East Asian countries in the late 1990s, followed by crises, most notably the crisis of Enron WorldCom in the United States in 2001. This has prompted the world to focus on governance.

\section{Governance Standards}

Due to the increasing interest in the concept of governance, many institutions have been keen to study this concept, analyze it, and set specific criteria for its implementation. These institutions include OECD, BIS, represented by the Basel Committee, and the International Finance Corporation (IFC) of the World Bank.

In fact, as the definitions of governance differed, the criteria governing the governance process differed, from the point of view of each of the parties to the concept of governance, as follows:

\subsection{OECD Standards for Corporate Governance}

Governance is implemented according to six criteria reached by the Organization for Economic Co-operation and Development (OECD) in 2004. These are:
A) Secure the foundations for an effective corporate governance framework:

Corporate governance promotes market transparency and effectiveness, is consistent with the rule of law, and clearly defines the distribution of responsibilities among the various supervisory, regulatory and executive authorities.

B) Shareholder's Rights and Key Functions:

Governance ensures that investors and shareholders are assured of an adequate return on their investments while maintaining their rights, especially holders of the equity minority.

C) Fair treatment of shareholders:

Equality between shareholders within each category, their right to defend their legal rights, to vote in the General Assembly on key decisions, as well as to protect them from any dubious acquisitions or mergers, or to trade in internal information, as well as their right to access all transactions with Board members or executives.

D) The role of stakeholders in corporate governance:

Governance serves to recognize the rights of stakeholders set forth in the law or through mutual agreements, and to promote effective cooperation between companies and stakeholders to create wealth, jobs and sustainable financial businesses.

\section{E) Disclosure and transparency:}

The Corporate Governance Framework ensures timely and accurate disclosure of the ownership of the majority of shares and the disclosure of Board members and CEOs. All such information is disclosed in a fair manner among all shareholders and stakeholders.

F) Responsibilities of the Board of Directors:

Corporate governance ensures strategic direction of the company, effective management oversight by the board of directors, and ensuring that the board is accountable to the company and shareholders.

\subsection{Standards of the Basel Committee on Global Banking Supervision}

In 1999, the Basel Committee established governance guidelines for banking and financial institutions, focusing on the following points:

- The values of the company and the charters of good behavior and other standards for the good conduct and the systems achieved by applying these standards.

- A well-prepared strategy for the company, under which its overall success and contribution of individuals can be measured.

- Proper distribution of responsibilities and decision-making centers, including a functional hierarchy of the required approvals of individuals to the Council.

- Establish a mechanism for effective cooperation between the Board of Directors, auditors and senior management.

- The availability of a strong internal control system that includes internal and external audit functions and independent risk management of lines of work, taking into account the suitability of authorities with checks and balances.

\section{Volume 6 Issue 12, December 2017}

www.ijsr.net

Licensed Under Creative Commons Attribution CC BY 


\section{International Journal of Science and Research (IJSR) \\ ISSN (Online): 2319-7064}

Index Copernicus Value (2016): 79.57 | Impact Factor (2015): 6.391

- Special monitoring of risk centers in locations where conflicts of interest arise, including working relationships with borrowers associated with the bank, senior shareholders, senior management, or key decision makers.

- Financial and administrative incentives for senior management to achieve work properly, as well as for managers or employees whether in the form of compensation, promotions or other elements.

- Flow of information internally or externally.

\subsection{International Finance Corporation (IFC) Criteria}

In 2003, the World Bank's International Finance Corporation (IFC) developed principles and standards for governance in different institutions at four levels:

- Acceptable practices of good governance.

- Additional steps to ensure good governance.

- Basic contributions to improving local governance.

- Leadership.

\section{Corporate Governance Determinants}

Corporate governance determinants increase confidence in national economies, activate and deepen the role of capital markets in mobilizing savings and raising the rates of return on investment, as well as protecting the rights of small investors and encouraging the private sector and its institutions to grow and increase their competitiveness. The key determinants of corporate governance are:

\subsection{Internal Determinants}

It refers to the rules and principles that determine how decisions are taken and the distribution of powers within the company between the General Assembly, the Board of Directors and the executive managers, which on the one hand and their application on the other hand reduce the conflict between the interests of these three parties.

- Mechanism of distribution of powers within the company.

- The mechanism, rules and rules governing how to make the fundamental decisions in the company.

- The structural relationship between the general assembly of the company and its board of directors and executive managers and the establishment of the appropriate mechanism for this relationship, thus alleviating the conflict between the interests of these three parties to achieve the integration of these interests.

\subsection{External Determinants}

It refers to the general climate of investment in the country, which includes elements:

- General laws regulating economic activity in general.

- The general climate of investment in the state.

- Efficiency of the financial sector from banks, insurance companies and financial markets that have an impact on finance.

- The level of competition in the markets of elements of production and the goods and services necessary for companies to carry out their productive activities.

- The existence, efficiency and capability of the SAIs, such as the presence of the Capital Markets Authority and its ability to control the business of companies, especially listed companies in the capital markets. - The existence of relevant professional associations, such as the Association of Lawyers and Accountants, auditing offices, credit rating, consulting, etc.

\section{Investment climate in Arab countries}

The concept of the investment climate has gradually expanded over time to encompass a complex combination of economic, political and social factors in which countries promote investment opportunities.

\subsection{The concept of the investment climate}

There are several definitions of investment climate, we refer to three definitions, including:

Definition 1: The investment climate refers to "the overall conditions and circumstances of the environment in which the investment process takes place, which includes the political and economic conditions, social, security, legal and administrative impact on the movement of capital and direction and directions"

Definition 2: The investment climate means "the overall political, economic, social and legal conditions affecting the direction of capital movement. Capital is usually characterized by cowardice and moves from bad to better."

Definition 3: The investment climate "means the total conditions and circumstances affecting the direction of capital flow and employment, where these circumstances include the political, economic, and efficiency and effectiveness of administrative regulations that must be appropriate and appropriate to attract and encourage domestic and foreign investments.

\subsection{Investment climate factors}

We note from the previous definitions that the investment climate is based on several elements, the most important of which are:

A. Political stability: Political stability is the first factor that the investor takes into consideration when making his decision

This factor includes the following elements:

- Developments in the general political situation and its stability,

- The type of government in terms of being a democratic or dictatorial,

- The extent to which the system of government acceptance or reluctance,

- The degree of political awareness in terms of the desire to allow foreign investments to participate in the process of economic and social development.

B. Economic and financial factors: They can be summarized as follows:

- The extent of the stability of investment laws and restrictions on the capital invested, and on the transfer of profits,

\section{Volume 6 Issue 12, December 2017}




\section{International Journal of Science and Research (IJSR) \\ ISSN (Online): 2319-7064}

Index Copernicus Value (2016): 79.57 | Impact Factor (2015): 6.391

- The stability of the inflation rate,

- The degree of competition within the host country, the ability to confront it,

- Extent of infrastructure,

- The resilience of the financial market to financial shocks,

- Flexibility of fiscal and monetary policy.

C. Social and cultural factors: They can be summarized in the following elements:

- The effectiveness of the approved educational, training, technological and training policy,

- Degree of awareness of the elements and elements of economic progress, and the degree of understanding and cooperation of members of society to the activity of foreign companies,

- The role of associations and trade unions in organizing and improving public forces,

- Degree of health awareness, and the amount of social insurance followed.

D. Market size and growth potential: The size of the market is measured by the number of inhabitants in the host country and per capita GDP.

E - Human factors: the availability of technical expertise and management and manpower trained to operate investment projects.

F- Structural factors: They are related to the basic infrastructure of transportation services, transport, communications, ports and airports, the establishment of industrial zones, water, sewage and storage, and others.

G. Geographical location Geographical location is an attractive factor for foreign investment. The proximity of the host country to the mother country and the extent to which it belongs to economic blocs reduces the costs of the investment activity on the one hand, and on the other ensures the export of products to member countries without restrictions or Hurdles.

\subsection{Incentives for Foreign Investment in the Arab States:}

There has been a competitive trend since the 1980s between developing countries, including Arab countries, to take a number of measures to provide more benefits and incentives to domestic and foreign investors.

Tax incentives Tax incentives can take several forms, including lowering the tax rate, adopting a tax deferral system, following accelerated depreciation, imposing discriminatory rates, transferring losses, and providing aid for investment.

The appropriate mix of tax incentives to attract foreign investment varies depending on the type of investment and the conditions of the host country. For Arab countries, most of them grant tax exemptions and exemptions from fees on capital invested, as follows:

- Tax exemptions: All Arab countries, except Somalia, are exempted from income tax, but this exemption varies in duration and amount from one country to another. For example,

- The period of exemption up to twenty years in Egypt, starting from the first fiscal year following the start of production or activity in the areas of encouraging regional development.

- Exemption period up to ten years in each of:

- Jordan for industrial and agricultural projects, hotels, hospitals, maritime transport and railways in percentages ranging between $25 \%$ and $75 \%$ of the value of the tax by location.

- Tunisia and $50 \%$ of the income of natural persons and companies active in the field of export, starting from the date or export.

- Algeria for investment in areas whose development requires special contribution by the State.

- Kuwait This period is linked to the percentage of national employment and development plans.

- Lebanon for investment projects to be established in areas classified as category (c).

- Exemption period of up to seven years in Syria for the joint companies that the State contributes by not less than $25 \%$ of the capital. The exemption shall commence from the date of actual production.

- Exemptions from fees: Arab investment laws have been granted some exemptions from payment of fees, the most important of which are:

- Libya: exempts the machinery, equipment and apparatus necessary for the implementation of investments from all customs duties and taxes, and taxes of similar effect, except for services (port fees, storage and handling).

- Morocco: exempts investment projects from the valueadded fee when importing them for all

A) Libya: Machinery, equipment and equipment necessary for the implementation of investments shall be exempted from all customs duties and taxes and taxes of similar effect, except for services (port fees, storage and handling).

- Morocco: exempts investment projects from value added tax when imported for machinery, equipment and equipment.

- Egypt: exemption of equipment goods and equipment and machines required for investment of all duties and customs taxes by $95 \%$.

B) Facilities and exemptions granted to the investor in free zones: The most important of which can be summarized in the United Arab Emirates as follows:

- Free zones shall be open to all types of goods from all national and foreign sources.

- Goods imported to free or manufactured areas shall be exempted from customs duties, and no customs duties shall be levied upon their export.

- Companies and individuals in the Free Zone shall be exempted from all taxes, including income tax, in respect of their operations within the Free Zone for a period of fifteen years renewable.

- Allows the establishment of factories, assembly plants and other industrial projects, and the practice of shipping, insurance, warehousing and any other commercial or financial business in the region. 


\section{International Journal of Science and Research (IJSR) \\ ISSN (Online): 2319-7064}

Index Copernicus Value (2016): 79.57 | Impact Factor (2015): 6.391

C) Guarantees for Investment: The most important guarantees granted to foreign investment in Arab countries can be summarized as follows:

- Respect for the investor's rights acquired in accordance with the previous investment law.

- It is not permissible to seize or nationalize a foreign investment except by law or through the judiciary.

- The right to transfer capital and profits.

- Resolving disputes between the investor and the host country.

Most of the Arab investment laws have put all the ways to resolve these disputes as follows:

- National judiciary

- National Arbitration

- International Arbitration

- Dispute resolution in accordance with international treaties.

In addition to the previous incentives, the efforts of the Arab countries focused on creating the economic environment conducive to attracting investment by deepening economic, monetary and financial reform, raising fiscal efforts, developing spending control tools to reduce the deficit to the acceptable limits, stabilizing inflation around acceptable levels, The Arab money in the face of financial shocks, deepen these markets and provide reasons for interdependence among them.

\subsection{Obstacles of foreign direct investment in the Arab countries}

Although most Arab countries seek to improve their investment climate by offering a number of incentives and guarantees to foreign investors, FDI inflows continue to suffer from many legal, legislative and administrative obstacles.

A. Legislative Constraints: Most Arab countries suffer from a state of legislative confusion, instability or stability of legislation regulating investments, which negatively affects the interests of foreign investors, and generates a sense of mistrust and confidence, along with restrictions on land ownership, Profits and mandatory local participation, which limit the opportunities for investment available.

B - Political instability: Most Arab countries suffer from political unrest, especially in the Middle East, which is the Arab-Israeli conflict on the one hand, and the US occupation of Iraq on the other, which spread fear in the hearts of investors and make them in anticipation of the disappearance of these unrest.

C - Administrative Complexities: The lack of coordination in the field of taxation and customs, and the weak efficiency of some human elements of the workers in the management of investment devices leads to the existence of bureaucracy and routine suffocation suffered by the investor, which requires him to deal with dozens of parties, and the issuance of dozens of permissions and permits since the introduction The investment request to obtain the official approval at every step is forced to pay bribes, otherwise his work is disrupted.
The lack of transparency of the Arab countries. This is because there is no database on economic activity available to the investor, and the lack of clarity among Arab governments regarding social and economic policies and labor laws.

E - weak infrastructure: The weakness of the infrastructure is an important factor in the decline in the volume of investment flows to the Arab countries, where the transfer is one of the most important impediments to investment in the Arab countries, so far the status of fleets of air transport deteriorating, and therefore the investor to export its products In civil aircraft or by individual coordination to reserve spaces in a large aircraft to transport their products to foreign markets to reduce costs.

Other obstacles: They can be summarized in the following points:

- Lack of clarity on the position of Arab governments on foreign direct investment.

- The shortage of foreign exchange available in the local market and the deterioration of the exchange rate of some Arab countries, reflecting the real value of investment denominated in foreign currencies and the profits of investors when they are transferred abroad.

\section{Role of Governance in Attracting Foreign Investment to Arab Countries}

\subsection{The Role of Governance in Attracting Foreign Investment}

Governance plays a major role in enhancing the competitiveness of the economy, as it works to attract investments, support economic performance and competitiveness in the long term through several methods,

- Emphasis on transparency in the company's transactions, and in the procedures of accounting and financial auditing, as the governance stands in the face of one of the parties to the corruption relationship, which leads to the depletion of the company's resources and erosion of competitiveness and therefore the departure of investors.

- Corporate governance procedures lead to improved management of the company, which helps to attract investments on good terms and improve the efficiency of the performance of the company.

- Adoption of transparency criteria in dealing with investors and with lenders can help to avoid the occurrence of banking crises.

- The application of corporate governance strengthens public confidence in the process of privatization and helps to ensure the state achieve the best return on investment, which in turn enhances the competitiveness of the state.

5.2 Governance and Foreign Direct Investment in the Arab Countries through some Global Indicators Although corporate governance is still in its infancy in the Arab countries and it faces some difficulties by some Arab companies listed in the financial market, As a result of its interference in its management policies, which negatively affects the level of disclosure and transparency and thus attracts foreign investment. However, a study by 


\section{International Journal of Science and Research (IJSR) \\ ISSN (Online): 2319-7064}

Index Copernicus Value (2016): 79.57 | Impact Factor (2015): 6.391

Transparency International on corruption rates in the world showed the UAE's application of high standards of governance and economic transparency Which made it ranked first in the Arab world and the world's thirty-one superior to the Arab countries.

Finland, Iceland, New Zealand, Denmark and Singapore ranked the top five globally as the world's most transparent and least corrupt (according to the same study). Countries such as Sudan, Guinea, Iraq, Myanmar and Haiti were among the five most corrupt countries in the world.

The UAE ranked first in the Arab world in the 2006 Corruption Perceptions Index, achieving 6.2 points compared with Qatar, which ranked second in the Arab world at 6 points, further evidence of the UAE's efforts to promote governance and transparency.

A) The Arab Corruption Situation Index: The Corruption Perceptions Index (CPI) has been issued annually since 1995 on Transparency International, which defines transparency as "exploiting public office for private interests". The index monitors the degree of transparency by measuring Extent of corruption among public sector employees and politicians, transparency ranges from 10 (very clean) to 0 (very corrupt).

Table 1: Indicators of Corruption in Arab Countries

\begin{tabular}{|c|c|c|c|c|c|c|}
\hline \multicolumn{3}{|c|}{2006} & \multicolumn{3}{|c|}{2008} & \multirow[t]{2}{*}{ الدولة } \\
\hline $\begin{array}{c}\text { Rank } \\
\text { Regional commissions }\end{array}$ & $\begin{array}{c}\text { Rank } \\
\text { Global }\end{array}$ & $\begin{array}{c}\text { sign } \\
\text { Indicator }\end{array}$ & \begin{tabular}{|c|} 
Rank \\
Regional commissions
\end{tabular} & $\begin{array}{c}\text { Rank } \\
\text { Global }\end{array}$ & $\begin{array}{c}\text { sign } \\
\text { Indicator }\end{array}$ & \\
\hline \begin{tabular}{c|}
$\mathbf{0 2}$ \\
\end{tabular} & 32 & 6.0 & \begin{tabular}{|r|}
01 \\
\end{tabular} & 28 & 6.5 & Qatar \\
\hline 01 & 31 & 6.2 & 02 & 35 & 5.9 & UAE \\
\hline 04 & 39 & 5.4 & $\mathbf{0 3}$ & 41 & 5.5 & Oman \\
\hline $\mathbf{0 3}$ & 36 & 5.7 & 40 & 43 & 5.4 & Bahram \\
\hline 05 & 40 & 5.3 & 05 & 47 & 5.1 & Jordan \\
\hline 07 & 51 & 4.6 & 06 & 62 & 4.4 & Tunisia \\
\hline 06 & 46 & 4.8 & 07 & 65 & 4.3 & Kuwait \\
\hline 11 & 79 & 3.2 & 08 & 80 & 3.5 & morocco \\
\hline 10 & 70 & 3.3 & 08 & 80 & 3.5 & KSA \\
\hline 12 & 84 & 3.1 & 10 & 92 & 3.2 & Algeria \\
\hline I & 1 & 1 & 11 & 102 & 3.0 & DJOUTEE \\
\hline 08 & 63 & 3.6 & 11 & 102 & 3.0 & LUBNAN \\
\hline 09 & 70 & 3.3 & 13 & 115 & 2.8 & Egypt \\
\hline 12 & 84 & 3.1 & 13 & 115 & 2.8 & MORTANIA \\
\hline 15 & 105 & 2.7 & 15 & 126 & 2.6 & Libya \\
\hline 16 & 111 & 2.6 & 16 & 141 & 2.3 & yamen \\
\hline 14 & 93 & 2.9 & 17 & 147 & 2.1 & Syria \\
\hline 17 & 156 & 2.0 & 1 & 1 & 1 & Sudan \\
\hline 18 & 160 & 1.9 & 18 & 178 & 1.3 & Iraq \\
\hline
\end{tabular}

Source: Transparency International

The 2008 index covered 180 countries, including 18 Arab countries, the same number as in 2007. The Corruption Perception Index for 2008 reflects the diverse nature of the Arab region, where 13 countries scored less than 5 indicators in the index, indicating a serious corruption problem. To only five countries that have scored more than 5 marks.

The results of the Corruption Perception Index for 2008 show that, despite the corruption and lack of transparency that continue to be a major challenge to regional development, structural reform steps are moving slowly. The fight against corruption in the public sector has gained momentum and legitimacy and is now clearly addressed as the main obstacle to development, from Morocco to Egypt, Lebanon, Jordan, Kuwait and Yemen. This momentum extends to Palestine although it is not included in the 2008 Corruption Perceptions Index.

The 2008 Corruption Perceptions Index shows lower levels of perceived corruption in Qatar, UAE, Oman, Bahrain, and Jordan. It is not yet clear whether these levels, especially in the oil and gas rich Gulf states, result from increased political will to combat corruption or reflect the capacity of large surpluses, which fuel rapid economic development and thereby help to mask the negative effects of corruption.

B) The development of foreign direct investment in the Arab countries: FDI inflows to the Arab region in 2007 rose for the year respectively, yet the percentage of these flows remained modest, at just $3.9 \%$ of the world total. The following table illustrates the evolution of foreign direct investment flows to Arab countries

Table 2: Development of FDI inflows to Arab countries During the period 2005-2007 [Million dollars and

$$
\text { percentages }
$$

\begin{tabular}{|c|c|c|c|c|c|}
\hline \multicolumn{2}{|c|}{2007} & 2006 & 2005 & YEARS \\
\hline 5 & 2577 & 48.2 & 2450 & 1653 & MOROCO \\
\hline 15 & 11578 & $80.6-$ & 1042.8 & 5376 & EGYPT \\
\hline $7-$ & 1665 & 66 & 1795 & 1080 & ALGRIA \\
\hline $40-$ & 1756 & 178 & 2915 & 1049 & Bahram \\
\hline $15-$ & 1618 & 323.5 & 3312 & 782 & TUNISIA \\
\hline 33 & 24318 & 51.2 & 18293 & 12097 & KSA \\
\hline $32-$ & 600 & 77 & 885 & 500 & SYRIA \\
\hline 616 & 1138 & $877.5-$ & 159 & 1298 & QUTAR \\
\hline 3 & 13253 & 17.5 & 12806 & 10900 & UAE \\
\hline
\end{tabular}

Volume 6 Issue 12, December 2017 www.ijsr.net 


\section{International Journal of Science and Research (IJSR) \\ ISSN (Online): 2319-7064}

Index Copernicus Value (2016): 79.57 | Impact Factor (2015): 6.391

\begin{tabular}{|c|c|c|c|c|c|}
\hline $43-$ & 1835 & 81.5 & 3219 & 1774 & JORDAN \\
\hline 4 & 2845 & 1.9 & 2739 & 2791 & LUBNAN \\
\hline 46 & 2377 & $3.9-$ & 1623 & 1688 & OMAN \\
\hline $1-$ & 153 & $81-$ & 155 & 814 & MORTANIA \\
\hline 11 & 21 & $59.5-$ & 19 & 47 & PLASTAIN \\
\hline 17 & 448 & $256-$ & 383 & 515 & IRAG \\
\hline 1 & 121 & $48-$ & 122 & 234 & KUWATE \\
\hline 19 & 195 & 178 & 164 & 59 & DJOUBTE \\
\hline 26 & 2541 & 94 & 2013 & 1038 & SOMALI \\
\hline 47 & 141 & 300 & 96 & 24 & LIBYA \\
\hline $59-$ & 464 & 471 & 1121 & $302-$ & YAMEN \\
\hline 60 & 72082 & 48.4 & 67853 & 45723 & $\begin{array}{c}\text { ARAB } \\
\text { COUNTREIES }\end{array}$ \\
\hline
\end{tabular}

The above table shows that the GCC countries topped the Arab countries in terms of attracting foreign direct investment, with the combined inflow rate reaching $60 \%$ of the total inflows to Arab countries in 2007.

The 2008 World Investment Report attributes the upward trend of inflows to the Arab region in 2005-2007 to a combination of several factors:

- More flexibility in the legislative framework of foreign direct investment in several countries of the region, especially in the field of financial services, real estate, and telecommunications, and privatization of these services has been an attraction for larger shares of investments through multinational companies.

- Economic growth in many Arab countries during the years (2005-2007).

- Oil prices continued to attract more investments into oil and gas related industries and services in 2007. Economic prosperity in oil-exporting countries has attracted new investments and many mega-mergers and acquisitions have been concluded across borders.

We also note that it is the Arab country that is the most applicable to the standards of governance (that is, ranked first in the Corruption Perceptions Index), which received the lion's share of foreign direct investment flows to the Arab countries. Based on this, And the corporate sector, which is the locomotive of progress and growth, in order to strengthen and stabilize the national economy, and improve the standard of living of citizens, and the welfare of society as a whole.

\subsection{Governance Challenges in the Arab States}

The inculcation of the principles of governance in Arab countries is a challenge in itself. The challenges facing the Arab economies include:

- The establishment of a system based on laws and not based on relations.

- Combating interests or acquired rights.

- The demolition of hierarchical property structures that allow the intruders to control the assets of many citizens and exploit them to achieve their interests only.

- Cut off the cross-cutting between banks and institutions.

- Establish effective systems that will determine the real owners even if the state is the owner.

- The separation of government and administration for the state being the largest contributor.

- Protect minority shareholders' rights.

- Search for active owners and competent managers.

- Strengthening the governance of family businesses.

- Developing technical and professional expertise.

\section{Conclusion}

Governance is one of the new requirements of Arab economies. This method is based on Disclosure and transparency. These are elements that are almost absent from the reality of the Arab region or are largely uncontrolled. Corporate governance is a way to enable the community to ensure that companies are well managed in a way that protects investors 'and lenders' money. More than ever, a transparent and fair system has been created to create safeguards against corruption and mismanagement, Arab economies to international competitiveness levels to attract more foreign investment

\section{References}

[1] Ibrahim Al-Esawi, Development in a Changing World: A Study on the Development Concept and Indicators. Cairo: Dar Al-Shorouk, 2003. pp. 36-37.

[2] Ahmed Munir Al-Najjar, The Banking Dimension in Corporate Governance, Kuwait Banks Union, Issue 40, March 2007

[3] Bassiouni (Mohamed Nazir), The Role of Economic Policies towards Foreign Direct Investment, PhD thesis, Ain Shams University: Faculty of Commerce.

[4] The National Bank of Egypt, the manner of exercising the powers of good governance in companies: corporate governance. Economic Bulletin No. 2, Vol.

[5] www.cipe-arabia.org/pdfhelp.asp World Investment Report.

[6] Warfare (Erekat), "The reality of the investment climate in the Arab world", Conference of Finance and Banking, Yarmouk University, 1988.

[7] Saleman (Duaa Mohammed), Policies of economic reform in creating investment climate, Master Thesis, Ain Shams University: Faculty of Merchants

[8] Fouad Shaker, Good Governance in Arab Banks and Financial Institutions According to International Standards, Paper presented to the 2005 Arab Banking Conference "The Partnership between Banking and Investment for Development", published in: Egyptian Banking Institute, Corporate Governance in the Banking Sector Workshop, March 2006.

[9] Qadi (Abdel Meguid), "Small and Medium Enterprises and Investment Climate", First Forum on Small and Medium Enterprises and their Role in Development, Laghouat University, 08-09 April 2002, pp. 24-25

[10] Qwaidri (Muhammad), Analysis of the Status and Prospects of Foreign Direct Investment in Developing Countries, $\mathrm{PhD}$ thesis in Economics, University of Algiers 2005

[11] KartinaKoshtaHelbleg, Corporate Governance in Emerging and Transition Economies, Center for International Private Enterprise,

[12] Arab Investment Guarantee Corporation, Investment Guarantee Bulletin 2005.

[13] Arab Investment Guarantee Corporation, Investment Guarantee Bulletin, Issue 3, 2008. 


\section{International Journal of Science and Research (IJSR) \\ ISSN (Online): 2319-7064}

Index Copernicus Value (2016): 79.57 | Impact Factor (2015): 6.391

[14] Mohamed (Abdel Ati), "Arab Investments Abroad", at: www.aljazeera.net, dated 09/08/2005.

[15] Mohamed (Mustafa Suwaid), "Proposed framework for tax incentives for investment to increase efficiency and rebalance the Egyptian tax society", the first scientific conference on investment strategy in Egypt in light of the challenges of the future, Faculty of Commerce, Zagazig University, Egypt, May 1995.

[16] Center for International Private Enterprise, Guide to Establishing Corporate Governance in Emerging Markets, www.cipe-arabia.org/pdfhelp.asp

[17] NermeenAbul Atta, Corporate Governance Progress, Working Paper, Egyptian Ministry of Foreign Trade, 2005. See: www.cpie-egypt.org

[18] Yunus (Shirin), "Foreign Direct Investment is an Economic Disaster or National Development", www.Islamtoday.net, 11/11/2006.

[19] Jensen and Meckling, "Theory of the Firm: Managerial Behavior, Agency Costs and Ownership Structure", Journal of Financial Economics, 1976, vol.

[20] Helbling, C, and J. Sullivan, "Introduction: Instituting Corporate Governance in Developing, Emerging and Transitional Economies", in Search for Good Directors, a Guide to Building Corporate Governance in the 21st Century, Center for International Private Enterprise, Washington, 2003, p.

[21] Nichlas S. Argyres; Julia Porter Liebeskind, "Contractual commitments, Bargaining power and governance inseparability: incorporating history into transaction cost theory", The academy of management review, vol 24, ${ }^{\circ} 01$, January 1999.

[22] Oliver Williamson, "Corporate governance", The Yale law journal, vol 93, ${ }^{\circ}$ 7, June 1984

[23] Organization for Economic Cooperation and Development, "Improving corporate governance standards: the work of the OECD and the Principles", Globe white page, 2004.

[24] Organization for Economic Co-operation and Development, "Principles of Corporate Governance", Economic Reform Journal, Issue n ${ }^{\circ}$. 4, October 2000.

Volume 6 Issue 12, December 2017 www.ijsr.net 